\title{
Thinking Muhammad Legenhausen's Non-Reductive Pluralism Through: Some Reflections about its Implications
}

\author{
STEFANO BIGLIARDI ${ }^{1}$
}

\begin{abstract}
One of the most vibrant contemporary philosophical debates concerns the definition, and defence, of religious pluralism. The philosophers who address such a topic usually hold widely divergent views regarding its exact definition and the arguments through which it can be upheld. The absence of a general consensus notwithstanding, the debate on religious pluralism has 'de facto' become an important area of dialogue between different religions in general, and between Christianity and Islam in particular. At stake in the present paper is the discussion of pluralism developed by the US-American-Persian philosopher Muhammad (Gary Carl) Legenhausen (b. 1953), that he presents as a criticism of the views of the late British theologian John Harwood Hick (1922-2012). Hick developed his views mainly influenced by Christianity, yet he also took into account some ideas advanced by Muslim authors. Legenhausen, a convert to Islam, puts forth his own version of pluralism in the framework of a discussion of the concept as it has emerged within Christianity, and advances a refutation of Hick's view complementary to his own theory of pluralism. The aim of the present pages is to offer an overview of Legenhausen's contribution and discuss some of its possible implications and premises. In other words, rather than producing a defence of Legenhausen's theory, this study is to analyse the logic behind and beyond his specific 'Muslim proposal' and explain what some of its unstated premises might be, as well as the consequences of fully embracing such stance, for philosophers, - not only Muslims ones -, interested in understanding religion from a religious point of view and in advocating that religious differences should not turn into a reason of animosity. The paper is divided into two main sections. The first one reconstructs Legenhausen's version of religious pluralism, while especially recalling the points with which it is presented as clashing with Hick's one. The second section is dedicated to the critical assessment.
\end{abstract}

Keywords: John Hick, Muhammad Legenhausen, philosophy, religious pluralism

The overall goal towards which the reflection of the British theologian J.H. Hick strives is the interpretation of religion from a religious point of view, attaining a justification of religion that focuses upon epistemological concepts and is not bound to a specific confession. Following Hick's theory, the basis of religion is an experience of the divine, which he calls 'the Real' as well as 'ultimate reality', and defines 'transcategorial' as: "beyond the range of categorial systems". Such experience, or encounter, is given through the human cognitive capacities and is later conceptualized through ideas that are culturally determined - hence the many names given in different cultures to the same Real. Religion as an institution, or as a corpus of doctrines, has the function both of a 'constant reminder' and of a 'filter' of the Real; in order to illustrate this latter point, Hick employs the image of a resistance in electronics (Hick 2004: xiii, xv, xix, xxi, xxv, 1,

\footnotetext{
${ }^{1}$ Stefano Bigliardi, Ph.D., Professor of Philosophy and Religion, Tecnologico de Monterrey, Campus Santa Fe, 01389 CIUDAD DE MÉXICO, Mexico, email: stefano.bigliardi@cme.lu.se.
} 
11 \& 163). Hick defines monotheistic creeds as post-axial religions - their emergence in his interpretation marked the realization not only of the existence of the Real but also of a 'limitless better possibility' disclosed to humanity, whereas pre-axial religions had rather been oriented to the creation of a more stable sense of life. The term 'axial' precisely emphasizes the reorientation of which consists, according to Hick, the liberation brought about by the major monotheistic religions. Such liberation is a transcending of the ego and the focus on humanity or, in other words, the shift of balance from self-centeredness to the Real; moreover, the emergence of post-axial religions meant, according to Hick, the exhaustive identification and establishment of the ways of conceiving the ultimate itself. The human beings on whose life the Real impinges more directly are the saints, who have (or have had) 'powerfully invasive experiences' stemming from the ultimate reality; beliefs can also be transmitted and inherited; therefore, more ordinary believers can be impressed by the moral and spiritual achievements of the saints; however, this is, according to Hick, a 'secondary kind of religious experience' (Hick 1990: 53, 55 \& 169; 2004: 12, 23, 28-31, 221-222, 230 \& 259).

Faith, either stemming from the direct acquaintance of the Real, or emerging as a result of 'second order' beliefs, is described by Hick as a cognitive choice: the choice to interpret the universe by assuming the existence and presence of God, seen as: "anti-improbability factor" and ". . . experiencing events in history and in our own personal life as the medium of God's dealings with us". The universe per se remains, as Hick maintains, 'stubbornly ambiguous' and cognitive religious experience can well be, as Hick admits, delusive. Hence, the cognitive choice of faith: "... has some of the characteristics of a wager". However Hick's central thesis is that it is rational to believe in God: "One who has a powerful and continuous sense of existing in the presence of God ought therefore to be convinced that God exists" (Hick 1990: 46 \& 58; 2004: 86, 104, 210, 216 \& 226). According to Hick: "a viable justification of religious belief . . leads inevitably to the problems of a religious pluralism". 'The great, postaxial world faiths' are described by him as: "embody[ing]) different perceptions and conceptions of, and correspondingly different responses to, the Real from within the major variant ways of being human ... within each of them the transformation of human existence from self-centredness to Reality is taking place". Such religions have emerged as the result of: "powerfully invasive experiences setting up new beliefs that were not compatible with much of the individual's previous belief-system". What can be said, then, about the contrasting and conflicting beliefs of different traditions? Hick classifies them under several categories and dismisses the idea that they constitute insurmountable difficulties. We have already seen that different religions basically are, as Hick defines them, different responses to the same noumenal dimension, and they therefore: ". . evoke parallel salvific transformations of human life". However, there are also 'opposed historical beliefs' that are at least theoretically solvable by means of historical evidence and that: "... should simply be acknowledged and tolerated". Hick categorizes conflicts regarding beliefs about creation, resurrection, reincarnation, heaven and hell (among others) as 'trans-historical'. He maintains that they concern questions whose answers are irrelevant for salvation/ liberation that, in any case, cannot be answered at the present time. The response to the inappropriateness of human concepts to them has been the creation of myths which, Hick asserts: "functioning in their separate mythic spaces, do not clash with one another" (Hick 2004: xv, 14-15, 230, 240 \& 370371).

One of the names of the Real that Hick lists is al-Haqq (Hick 2004: xl, 11, 48-50, 237, 241, 373 \& 378), one of the names of God in Islam. The Islamic call that: "There is no god but God" (la ilaha illa Allah) is listed by Hick among those primary affirmations of faith that: ". . . typically contain an explicit or implicit summons to respond..." and conflict only in the sense that: ". . . they are different and that one can centre one's religious life wholeheartedly and unambiguously upon one of them". In opposition to the idea that pluralism is historically Western or Christian, Hick identifies it in the teaching of, among others, the Sufi Rumi (12071273 CE) and quotes this saying: "The lamps are different but the Light is the same: it comes from 
Beyond". With an analogous function, Hick refers to the Sufi al Junaid (830-910 CE) who stated: "The colour of the water is the same as that of its container" a metaphor that well described, according to Hick, the way in which different religions experience and conceptualize the Real. Islam, Hick remarks, has no concept of salvation or of humanity's fall; however, he points out that it precisely distinguishes between self-surrender to God, leading to peace and the contrary state. In this sense Hick relates the state of Islam as parallel to Christian and Judaic salvation as well as to Hindu and Buddhist liberation. Hick also highlights a special awareness of the: ". . . transformation of human existence by the total surrender of the self to God" that he sees exemplified in Sufism through the concepts of dhikr or 'God-consciousness' and fana or: "recentring in God leading to 'baqa', human life merged into the divine life. . .". 'Islam', Hick concludes: "is thus very clearly a form of the transformation of human existence from selfcentredness to Reality-centeredness". As to the future of Islam, Hick states that: "Islam may be expected to go through essentially the same traumas as Christianity in its encounter both with modern science and with the emerging ecumenical outlook"; Hick identifies such ecumenical outlook within the Muslim world as 'powerfully expressed' by Sufism and therefore utters the hope in a full acknowledgement of it.

Muhammad Legenhausen (1999: 27, 31-46 \& 79-90; 2006: 7-8, 19-26, 29-39, 46 \& 63) defines religious pluralism as: ". . . a doctrine according to which some sort of favourable attribution is ascribed to a plurality of religions". He points out that the term in a metaphysical sense was first employed by the German philosopher Christian Wolff (1679-1754), that it was later popularized by the US-American William James (1842-1910), and that it tends to be confused with a term used in a political sense. Legenhausen goes on to identify at least seven variants of pluralism, with possible sub-variants, and conducts a historical survey aimed at demonstrating that: ". . . modern religious pluralism arose specifically in reaction to widespread Christian views about salvation". However, it is especially in contrast with Hick's doctrines that Legenhausen advances his own version of pluralism. Hick is indeed presented by Legenhausen as the foremost advocate of reductive pluralism, i.e., of a form of pluralism that Legenhausen opposes. According to Legenhausen, the British theologian's proposal is mined by several serious difficulties. First of all, according to him, Hick's religious pluralism, while presented as a doctrine of toleration, is in fact a doctrine of 'mutilation': ". . the advocacy of a forced doctrinal synthesis . . . intolerant of serious religious differences". Secondly, Hick's doctrine, in Legenhausen's view, falsely considers the differences between religions as 'doctrinal' rather than "practical." Third, Hick downplays the relevance of differences in doctrines and in so doing, weakens religious prescription, as Legenhausen affirms. Fourth, in Legenhausen's interpretation, Hick's advocacy of religious pluralism tends to lessen the importance of reason that is instead an important instrument in the settlement of religious disputes and, generally, in theological discussions. Fifth, according to Legenhausen's interpretation, Hick falsely refers to mysticism as a justification of belief. Finally, Hick's religious pluralism, as Legenhausen maintains, is rooted in political liberalism that cannot be reconciled with all world religions.

We have already observed in some detail Hick's references to Islam. Legenhausen is especially critical of Hick's passage regarding the encounter of Islam and modernity (and possibly mediated by Sufism) that was quoted at certain length beforehand. Legenhausen criticizes this passage for having a patronizing tone, and he tries to undermine Hick's reference to Sufism and to Rumi's motto. Legenhausen does assert the validity of some 'degenerate' Sufi movements that have initiated non-Muslims, but still maintains that the 'vast majority' of them are required to embrace shari'ah prior to spiritual initiation. Furthermore, in order to water down the supposed pluralistic vein in Rumi's metaphor with the lamps and the light, Legenhausen remarks that the Qur'an does distinguish among different religions despite the identity of such light: ". . rather God presents the lamps to humanity in succession and it is our responsibility to follow what God has assigned for us at the present age". According to Legenhausen, there is only one emphatic difference between Sufism and theology with regards 
to religious diversity, the former: ". . emphasize the inner unity of revealed religions, while the theologians emphasize the outward superiority of Islam" (Legenhausen 1999: 107-110; 2006: 84, 88 \& 98).

It is in the framework of this reconstruction of pluralism, and of the criticism of Hick's specific version of pluralism, that Legenhausen puts forth his own proposal that he labels as non-reductive. The gist of non-reductive pluralism, according to Legenhausen, is: “. . the view that each of a number of religions has unique features through which God may guide people, even if there is no common essence to all religions". According to Legenhausen, this version of pluralism: ". . . is able to avoid the objections raised against liberal or reductive pluralism while maintaining an attitude of tolerance and rejecting prejudice". Non-reductive pluralism as Legenhausen develops it is presented by him as deeply rooted in Islam, which in turn is presented as essentially legalistic: "No matter how we miserably fail", Legenhausen remarks: "Muslims aspire to build a society founded on the example of the Prophet's just governance in accordance with Divine law". Moreover, Legenhausen points out that to have faith in the Islamic sense: ". . . is to be wholeheartedly committed to believe 'in' as well as to believe 'that', and to be ready to put one's beliefs into action". Therefore, according to Legenhausen, a distinction must be maintained between Islam and other religions, especially pre-Islamic paganism which cannot be described as solely one response to the Real among others. Moreover, he points out that accepting only some of the prophets to the exclusion of others (most notably the Prophet of Islam): ". . with the excuse that it makes no difference because all religions are ultimately saying the same thing is to fail to heed the divine call" (Legenhausen 1999: 101 \& 103; 2006: 4 \& 65).

Therefore, non-Muslim religious devotion should be interpreted as a mistake, according to Legenhausen (2006: 111, 115, 118, 121 \& 123-128); however he adds: "Since there is no way for us to tell whether or not the mistake is excusable, where good relations with non-Muslims are possible without condoning injustice, the presumption of an 'honest mistake' is morally incumbent on us". No attempt is therefore made to reinterpret doctrines and beliefs: ". . to reveal some hidden agreement". In sum, what Legenhausen prescribes is an admission of humility, the acknowledgment that we do not know how God may guide the sincere, that according to him: ". . . has featured prominently in the Islamic tradition". It is also taken for granted that each believer considers his or her own faith tradition as the best. Legenhausen asserts that: "to defend religion means to support, encourage and defend the dignity of others' faiths and practices to the greatest extent possible" yet he immediately admits that such an approach is not 'unlimited' i.e. devoid of difficulties). Perhaps as a counterbalance to Hick's reference to Rumi, Legenhausen reports a story to be found in Rumi's poetry; according to this story, Moses once scolded a shepherd who expressed his faith in God in rather naive a way, only to be told by God in person that this form of worship had been accepted. Yet the story, Legenhausen points out, also recounts that Moses narrated to the shepherd what had happened, who in turn thanked him for prodding him to move to a higher form of worship.

\section{Thinking Legenhausen's Pluralism Through}

I here take the act of 'thinking through', evoked by the title in reference to my own attitude towards Legenhausen's doctrine, to mean the critical interpretation of a philosophical teaching according to different perspectives, and on different levels. My goal is to think through Legenhausen's non-reductive pluralism especially paying attention its the broader and farthestreaching implications, i.e. to the stances that one should consequently and consistently assume towards other religions or teachings that are more sweepingly touched upon by the thinker while advancing his theory. To begin with, it should be remarked that apparently Legenhausen's theory of pluralism is subject to diverse interpretations or evaluations, most of them complementary. Thus, I shall sketch a list of possible lines of investigation or assessment that 
shall not pursued at any length on these pages, and that here are offered to my reader not only for completeness' sake but also as suggestions for further investigation and reflection:

- One might engage in a socio-historical reading of the emergence of Legenhausen's teaching. The information provided in the preceding section and the very fact that Legenhausen's contribution is quite recent render this kind of attempt premature here; furthermore, it definitely exceeds my own competence as a scholar. However, it seems relevant to point that the fact that theories blossomed over the past decades upholding religious pluralism might be considered, besides and beyond their specific theologico-philosophical consistency and value, as the result and expression of their inventors' existential experiences linked to and rooted in social shifts characteristic of modernity. In other words, the urge for the development of some form of religious pluralism can be generally seen as a result of globalization, which rendered, at least for a considerable number of intellectuals, the perception of religious diversity, as well as the need for a pacific coexistence argued on a rational (or at least persuasive) basis, inescapable. The specific need, felt and expressed by a figure like Legenhausen, for a non-reductive, Muslim contribution (i.e. a position that is pluralistic yet at the same time quite intransigent towards attempts perceived by him as too weak or lenient with existing contradictions among religious creeds) might be explained as mirroring (or stemming from) Legenhausen's specific condition of an US-American convert and academic and, what is more, immersed in the context of contemporary Iran.

- One might engage in an evaluation of Legenhausen's reading of Hick's theory. What I have offered to my reader is however a simplified (or perhaps even biased) version of the British theologian's doctrine, functional to the illustration of Legenhausen's one. It can also be further discussed up to which extent Legenhausen's doctrine is essentially dependent upon his own criticism of Hick's. Undoubtedly, the fact that Legenhausen takes Hick's contribution as its main polemical objective might be considered as a factor that bestows supplementary interest and visibility on Legenhausen's one, given the predecessor's fame and importance; and yet, if Legenhausen's interpretation would be proved wrong or unsatisfactory, up to which extent would his specific non-reductive pluralism turn out to be weakened as to its tenets? This question is left open for the specialists of Hick's theory.

- One might undertake a theological evaluation of Legenhausen's theory, comparing it to the content of relevant Qur'anic passages and trying to understand up to which extent such teaching can be substantiated with punctual quotations from the Revelation and, more in general, whether and how it can be reconciled with broader theological doctrines.

As stated above, the points will not be deepened here. We might call them questions regarding the premises of Legenhausen's theory - in other words, such questions touch upon all those elements that precede Legenhausen's theory, in a broad sense, as factors that motivate its emergence or as its philosophico-theological foundations. What is at stake in what follows are rather what I define the implications (once again, in a broad, not exclusively or strictly logical sense) of Legenhausen's teaching. What guides me in the identification of such implications is the following overarching question; what ideas are we bound to embrace if we, as philosophers, or theologians, Muslim and non-Muslim alike, subscribe to such a position, beyond the specific rejection of Hick's teaching? A parallel question that shall be explored is; what kind of philosophical style might be most congenial to a Legenhausen-inspired doctrine of religious pluralism? Let us start with the acceptance of the irreducible asymmetry between revelations and therefore between religions that, as we have seen, is at the core of Legenhausen's position. This asymmetry overlaps with, or is induced by, the full acceptance of the doctrine according to which the revelation received by the Prophet of Islam completes and seals the previous ones. Such acceptance seems to entail dramatic consequences for at least three lines of reflection according to which theologians and philosophers have been trying to argue not only in favour of religious pluralism proper but also, more generally, in order to lessen the believers' initial diffidence towards other creeds. 
The first line of argumentation is the one aimed at highlighting the analogies between different religions; such strategy has a long and honourable history; we can for instance recall here the declaration Nostra Aetate, stemming from the Second Vatican Council and promulgated by Pope Paul VI (1965), that emphasizes the similarities between Christianity and other religions. One passage, about Islam, is particularly worth to be quoted at length here:

The Church regards with esteem also the Moslems. They adore the one God, living and subsisting in Himself; merciful and all-powerful, the Creator of heaven and earth, who has spoken to men; they take pains to submit wholeheartedly to even His inscrutable decrees, just as Abraham, with whom the faith of Islam takes pleasure in linking itself, submitted to God. Though they do not acknowledge Jesus as God, they revere Him as a prophet. They also honour Mary, His virgin Mother; at times they even call on her with devotion. In addition, they await the Day of Judgment when God will render their deserts to all those who have been raised up from the dead. Finally, they value the moral life and worship God especially through prayer, almsgiving and fasting. Since in the course of centuries not a few quarrels and hostilities have arisen between Christians and Moslems, this sacred synod urges all to forget the past and to work sincerely for mutual understanding and to preserve as well as to promote together for the benefit of all mankind social justice and moral welfare, as well as peace and freedom.

A second, more sophisticated or academic line, is aimed at elaborating common ground between different religions, for instance by emphasising the analogous challenges posed to all religions by (a certain reading of) natural science, and therefore the analogous ways in which the former might cope with the latter. A third line is the one aimed at synthesizing a common core-creed between different religions - this is precisely the line that, at least in Legenhausen's interpretation, Hick was wrongly pursuing.

Embracing Legenhausen's philosophy implies, in my view, at least two main consequences as to such lines of thought. On the one hand, the very emergence of such contributions as an intellectual phenomenon should not be rejected in toto: they still might be seen as animated by an urge analogous to the one that motivates Legenhausen, and therefore a morally or practically laudable one, even if framed into what, as we have seen, Legenhausen calls a honest mistake. However, on the other hand, their philosophico-theological value turns out to be severely questioned and weakened. Legenhausen points out, as we have seen, multiple and irreparable asymmetries between revelations and religions, given the fact that different revelations have been bestowed on humanity in different times, that some teachings have been corrected or cancelled by successive ones, or that some pivotal figures (first and foremost Jesus), are characterized in deeply divergent ways. Hence, mentioning that the same narrative or figure occurs within all such revelations or religion (for instance Abraham, or Moses, or the Virgin Mary) is an important and interesting analogy to be highlighted, (especially as a counterbalance to the attempts, sadly very frequent in some political circles, at excessively 'exotifying' other religions in order to induce feelings of fear and refusal), but such highlighting it is not tantamount nor conducive to the construction of a 'common creed', nor should it be used to induce the illusion thereof, or that the similarities are more relevant than the dissimilarities: substantial doctrinal differences exist and persist. An analogous assessment is obtained, in this vein, as to the second and third line of argumentation: if we adopt Legenhausen's standpoint we can state that these theories just (try to) cloud the inescapable, essential differences between religions, and represent, at best, an expression of analytical skills that might be invested in the construction of more significant theologico-philosophical doctrines.

A final, but not less, relevant, question is; which philosophical style should we adopt in order to express a defence of religious pluralism à la Legenhausen? Indeed the US-AmericanIranian occasionally seemed to favour a 'geometrical demonstration' of his arguments, i.e. to tend to the adoption of an analytical style, he does appreciate and practice such style 
(Legenhausen 2009: 5-42), characteristic of the form of philosophy to which he was exposed in the first phases of his intellectual development, yet he also states: "I still like the logic chopping of analytic philosophy, and its clever ways of dealing with paradoxes and quandaries. Too often, however, it seems to suffer from a lack of spirit, a lack of profundity, a lack of faith. Of course, there are exceptions; but as a rule, analytic philosophy seems to share many of the vices that pervade contemporary post-industrial society: over-reliance on technical expertise and over-specialisation, over-confidence that science can answer all the questions worth asking" (Legenhausen 2006a: 2). We have observed that Legenhausen is eager to recognize and make explicit the difficulties that his position entails, as well as to defend his version of pluralism even in a narrative, although essentially philosophical way, as it is the case with the above-mentioned apologue of Moses and the shepherd.

Perhaps I can sum up all the suggestions contained in the preceding pages by drawing a comparison between the role potentially played by Legenhausen in the contemporary debate over religious pluralism and the appearance, in Western philosophy, of the ideas of the ideas of the Danish philosopher Søren Aabye Kierkegaard (1813-1855) within a philosophical landscape dominated by those of the German philosopher Georg Wilhelm Friedrich Hegel (1770-1831). In nuce, Hegel conceived an interpretation of human spirit and history (the latter being considered as the unfolding of the former) as a process constantly shaped in a threefold abstract movement; thesis, antithesis, and synthesis. In this process the elements of whatever is perceived (or initially thought of) as a contradiction or a conflict, are subsequently 'elevated' and 'conserved' (German aufgehoben) in a superior, synthetized unity. Such logical mechanism is systematically identified or applied by Hegel in his interconnected interpretations of knowledge, history, and art. Kierkegaard's thought is instead centred on individual and existence. The latter, for the Danish author, is not an attribute of universal concepts, that are abstract generalizations, but rather of the single individual. The very verb ex-sistere, according to Kierkegaard, points at the fact that the individual out-stands, i.e. is distinguished and unrepeatable. Reality and singularity, in his interpretation, converge. Therefore, in Kierkegaard's criticism, Hegel's threefold 'movement' might well prove a fascinating intellectual tool for the production of all-encompassing systems; however, a single individual never experiences such synthesis but rather radical choices or dilemmas, that come in the form of an aut-aut, either-or, and where no third way or compromise is given. Furthermore, to Hegel's constant emphasis on rationality and to his meticulous, analytical style Kierkegaard (who preferably defined himself a poet) opposed a fragmentary, poetic, and narrative form, and especially accentuated the treatment of feelings.

Analogously, I am inclined to see Legenhausen's philosophical contribution as a clarioncall to all the advocates of religious pluralism (broadly meant), towards which he acts in a way analogous to that of Kierkegaard's philosophy to Hegelianism. Whereas he advocates practical, concrete pluralism, i.e. the idea according to which religious diversity should not become the reason for animosity, and that believers of other creeds should be considered and treated in a benevolent way, Legenhausen dramatically reshuffles the cards traditionally played by the advocates of pluralism. Similarly to Kierkegaard's approach to life and history, Legenhausen's theory does not escape from radical asymmetries: on the contrary, it emphasizes them - they become the cornerstone of his position. Embracing such position requires a courageous thinker who is not afraid to look eye-to-eye with the radical differences present in other religions, as well as with the contradictions, doubts, and mixed feelings apparently arising from the confrontation with his or her own sacred scriptures, or more in general with any opposing positions that arise from one's own traditions.

Legenhausen's stance, if assumed as a method rather than a specifically Muslim position, uncompromisingly assumes the insider view's perspective of a specific religious tradition, avoiding the illusion and the impression of creating a 'synthesis' of beliefs served to her or his readers in a rationalized packaging, and never forgetting radical differences in favour of 
analogies and abstraction. Such an approach to religious pluralism is not be an Olympian, irenic and analytical theory, but rather a philosophy practiced with courage and self-criticism, also liable to be expressed in a narrative style rather than one that tailored on systematic, analytical philosophy. All this has far-reaching and perhaps dramatic consequences, that shall be further explored in detail, and that pose substantial challenges, especially for thinkers interested in the development of such an approach from a Jewish or Christian standpoint.

\section{References}

Hick, John. 1990. A John Hick Reader. Ed. by Paul Badham. London: MacMillan.

Hick, John. 2004. An Interpretation of Religion: Human Responses to the Transcendent. 2nd Ed. New York: Palgrave MacMillan.

Legenhausen, Muhammad. 1999. Islam and Religious Pluralism. London: Al-Hoda.

Legenhausen, Muhammad. 2006. A Muslim's proposal: Non-reductive religious pluralism. http://www.uibk.ac.at/theol/leseraum/texte/626.html. [11 January 2014].

Legenhausen, Muhammad. 2006a. From an existentialist to a Muslim. http://www.imamreza.net/eng/imamreza.php?id=3595. [11 January 2014].

Legenhausen, Muhammad. 2009. On the plurality of religious pluralisms. International Journal of Hekmat 1: 5-42. 